\title{
PEMBERIAN PROBIOTIK LACTOBACILLUS BREVIS DAN PREBIOTIK OLIGOSAKARIDA PADA BENIH PATIN SIAM (Pangasionodon hypophthalmus) YANG DIINFEKSI Aeromonas hydrophila
}

\author{
Yuke Eliyani"), Widanarni"*), dan Dinamella Wahjuningrum ${ }^{* *}$ \\ *) Sekolah Tinggi Perikanan Jurusan Penyuluhan Perikanan \\ Jl. Cikaret No. 2 Bogor 16000 \\ **) Departemen Budidaya Perairan-FPIK, Institut Pertanian Bogor \\ JI. Lingkar Akademik, Kampus IPB Darmaga, Bogor 16680 \\ E-mail:yukeeliyani@yahoo.co.id
}

(Naskah diterima: 20 April 2013; Disetujui publikasi: 10 Mei 2013)

\begin{abstract}
ABSTRAK
Penelitian ini bertujuan untuk mengevaluasi pengaruh pemberian probiotik Lactobacillus brevis, prebiotik oligosakarida dan sinbiotiknya terhadap jumlah bakteri Lactobacillus sp. dan total bakteri dalam usus, total eritrosit, total leukosit, diferensial leukosit, aktivitas fagositik, sintasan, tingkat pertumbuhan, serta FCR benih ikan patin siam yang diinfeksi Aeromonas hydrophila. Hasil uji karakteristik menunjukkan bahwa jenis probiotik dan patogen adalah Lactobacillus sp. dan Aeromonas hydrophila. Pada uji in vivo digunakan lima perlakuan yang terdiri atas $\mathrm{K}(+), \mathrm{K}(-)$, probiotik (pro), prebiotik (pre) serta sinbiotik (sin). Bakteri Lactobacillus sp. ditemukan di usus pada perlakuan probiotik dan sinbiotik dengan kisaran jumlah sekitar $10^{1}$ sampai $10^{6}$ (CFU/gram). Total eritrosit, total leukosit, aktivitas fagositik berbeda nyata $(P<0,05)$ dengan kontrol pada beberapa waktu pengamatan. Tingkat sintasan terendah diperoleh pada perlakuan $\mathrm{K}(+)$ sebesar $43,33 \pm 11,55$; sedangkan empat perlakuan lainnya memperoleh nilai $100 \%$. Tingkat pertumbuhan harian berbeda nyata antar perlakuan, nilai terbaik dicapai pada perlakuan pemberian sinbiotik sebesar $3,370 \pm 0,14$. Nilai FCR perlakuan probiotik, prebiotik dan sinbiotik menunjukkan beda nyata dengan kontrol. Perlakuan sin, pre, pro memberikan nilai yang lebih baik pada total eritrosit, total leukosit, aktivitas fagositik, sintasan, pertumbuhan, dan FCR dibandingkan kontrol.
\end{abstract}

KATA KUNCl: probiotik, preboitk, sinbiotik, Lactobacillus brevis, Aeromonas hydrophila, Pangasionodon hypophthalmus

ABSTRACT: The application of probiotic Lactobacillus brevis and prebiotic Oligosaccharides for thai catfish seeds (Pangasionodon hypophthalmus) which infected by Aeromonas hydrophila. By: Yuke Eliyani, Widanarni, and Dinamella Wahjuningrum

The aim of this study was to evaluate of probiotic Lactobacillus brevis, prebiotic Oligosaccharides and synbiotic upon the population density of Lactobacillus sp. and total bacteria in the intestine, total erythrocyte, total leucocyte, phagocytic activity, survival (SR) and growth rate (SGR) and feed conversion ratio (FCR) of Thai Catfish seeds (Pangasionodon hypophthalmus) which was infected by Aeromonas hydrophila. The results of the caracteristic test showed that the species of probiotic and pathogen were Lactobacillus brevis and Aeromonas hydrophila. In vivo test was carried out in 5 (five) treatments, i.e. positive control $(K(+))$, negative control (K()), probiotic (Pro), prebiotic (Pre) and synbiotic (Sin). The results showed that the total 
number of Lactobacillus sp. in the gut were between $10^{1}-10^{6}$ (CFU/gr) and analysis of erythrocyte, leucocyte, and phagocytic activity have shown significant different $(P<0.05)$ with control. The treatment of $K(+)$ revealed lowest survival rate $(S R)(43.33$ $\pm 11.55) \%$, while other treatments $S R$ were at $100 \%$. The growth rate showed significant different $(P<0.05)$, with the highest value was on Sin treatment $(3.37 \pm 0.14) \%$. The $F C R$ showed significant different $(P<0.05)$ of Sin, pre, pro to control. This fact suggested that pro, pre, and sin are more better than control at total erythrocyte, total leucocyte, phagocytic activity, $S R, S G R$, and FCR.

KEYWORDS: probiotic, prebiotic, synbiotic, Lactobacillus brevis, Aeromonas hydrophila, Pangasionodon hypophthalmus

\section{PENDAHULUAN}

Ikan patin siam (Pangasionodon hypophthalmus) merupakan salah satu jenis patin yang banyak dibudidayakan di Indonesia, serta menjadi salah satu komoditas unggulan sektor perikanan. Salah satu penyakit yang ditemukan pada budidaya patin adalah penyakit yang disebabkan oleh infeksi bakteri Aeromonas hydrophila. Rey et al. (2009) menyatakan bahwa bakteri $A$. hydrophila memproduksi faktor-faktor virulensi berupa eksotoksin yang penting dalam patogenitas, salah satunya adalah enzim proteolitik yang dapat merusak dinding intestin inang hingga terjadi oedema. A. hydrophila merupakan bakteri penyebab penyakit yang banyak ditemui dalam budidaya perairan, dan dikenal dengan Motil Aeromonad Septicaemia (MAS). Berbagai langkah pengobatan telah dilakukan untuk mengatasi penyakit ini, umumnya melalui penggunaan obat kimia. Permasalahan pada saat penggunaan obat kimia di lapangan, antara lain dosis dan waktu pemberian obat yang tidak tepat. Akibatnya dalam jangka panjang dapat menimbulkan dampak resistensi bagi bakteri A. hydrophila terhadap obat yang diberikan. Berkenaan dengan hal tersebut, maka dicari berbagai alternatif, di antaranya melalui pemanfaatan probiotik dan prebiotik.

Probiotik merupakan mikroorganisme hidup, yang mempunyai pengaruh menguntungkan pada kesehatan inang dengan memperbaiki keseimbangan mikrobiota intestinal. Efektivitas probiotik ditentukan oleh kemampuannya dalam memberikan efek menguntungkan bagi inang karena sifatnya yang tidak patogenik, tidak toksik serta juga kemampuannya bertahan dan melakukan kegiatan metabolisma dalam usus (Douglas \& Sanders, 2008). Penggunaan probiotik dalam lingkup akuakultur dapat diaplikasikan dengan mencampurkannya dalam pakan, agar dapat menyeimbangkan kondisi mikrobiota dalam saluran pencernaan sehingga diharapkan dapat menurunkan pengaruh serangan patogen (Verschuere et al., 2000). Bakteri yang dapat digunakan sebagai probiotik diantaranya adalah dari golongan Lactobacillus. Park et al. (2008) menyatakan bahwa terdapat paling tidak beberapa jenis bakteri dari golongan Lactobacillus yang termasuk agen probiotik. Angelis \& Gobbeti (2011) menyatakan bahwa Lactobacillus spp. termasuk pada kelompok bakteri asam laktat sehingga aman bagi pencernaan.

Prebiotik didefinisikan sebagai bahan pangan yang tidak dicerna oleh inang, dapat difermentasi oleh mikrobiota saluran pencernaan, mampu secara selektif menstimulasi pertumbuhan dan aktivitas bakteri pencernaan (Merrifield et al., 2010). Ada beberapa jenis prebiotik antara lain fructooligosaccharide (FOS), Galactooligosaccharide (GOS), serta inulin (Patel \& Goyal, 2012). Narges et al. (2012) menyatakan bahwa Prebiotik juga secara tidak langsung dapat memberikan efek imunologi. Larva ikan Caspian roach (Rutilus rutilus) dengan perlakuan pemberian pakan yang dicampur FOS sebanyak 2\% menunjukkan adanya peningkatan respon imun non spesifik, kemampuan bertahan terhadap stress, aktivitas enzim pencernaan serta tingkat pertumbuhan yang lebih baik dibandingkan dengan kontrol. Penggunaan GOS dapat menstimulasi perbanyakan bakteri Lactobacillus sp. pada inangnya (Davis et al., 2010).

Gabungan dari probiotik dan prebiotik dikenal dengan sebutan sinbiotik seperti halnya bakteri Lactobacillus sp. dengan oligosakarida. Keuntungan dari pencampuran kedua bahan ini adalah adanya peningkatan daya tahan hidup bakteri probiotik karena telah 
tersedianya nutrisi yang spesifik untuk kebutuhannya. Hasil penelitian Merrifield et al. (2010), menunjukkan bahwa suplemen sinbiotik (kombinasi probiotik dari golongan bakteri asam laktat dan prebiotik oligosakarida), berpengaruh positif pada pertumbuhan dan aktivitas bakteri pencernaan ikan salmon.

Penelitian ini bertujuan untuk mengevaluasi pengaruh pemberian probiotik L. brevis, prebiotik oligosakarida dan kombinasinya (sinbiotik) terhadap populasi bakteri Lactobacillus sp. dan total bakteri di usus, gambaran darah, sintasan, tingkat pertumbuhan serta FCR benih ikan patin siam yang diinfeksi $A$. hydrophila.

\section{METODE PENELITIAN}

\section{Waktu dan Tempat Penelitian}

Penelitian dilaksanakan mulai bulan Oktober sampai dengan Desember tahun 2012 di Laboratorium Kesehatan Ikan, Institut Pertanian Bogor; Sekolah Tinggi Perikanan Jurusan Penyuluhan Perikanan Bogor; dan Balai Besar Pengembangan Budidaya Air Tawar Sukabumi.

\section{Karakterisasi Bakteri}

Karakterisasi Lactobacillus sp. dan A. hydrophila dilakukan menggunakan Analytical Profile Index (API), yaitu API $50 \mathrm{CH}$ untuk Lactobacillus sp. dan API 20 E untuk A. hydrophila. Hasil uji karakterisasi bakteri menunjukkan spesies bakteri yang digunakan untuk probiotik adalah $L$. brevis dan untuk uji tantang adalah A. hydrophila.

\section{Analisis Prebiotik}

Analisis kandungan oligosakarida dalam sampel prebiotik dilakukan dengan Metode HPLC (AOAC, 1999). Kolom yang digunakan adalah bondclone $10 \mu \mathrm{m} \mathrm{NH}_{2}$, dengan detektor refractive index berlaju alir 1-1.2 mL/menit. Fase gerak yang digunakan adalah asetonitril dan air dengan perbandingan asetonitril: air $=$ 80 : 20. Volume sampel yang diinjeksikan adalah $20 \mu \mathrm{L}$. Standar gula yang digunakan adalah fruktooligosakarida (FOS), dan galaktooligosakarida (GOS). Berdasarkan hasil perhitungan diketahui bahwa nilai prebiotik FOS dan GOS yang diperoleh sebesar 3.448 $\mathrm{g} / 100 \mathrm{~g}$ dan $1.08 \mathrm{~g} / 100 \mathrm{~g}$.

\section{Penentuan LD50 bakteri $A$. hydrophila}

Benih ikan patin siam (Pangasionodon hipophthalmus) dengan panjang rata-rata 9,1 $\pm 0,19 \mathrm{~cm}$ dipelihara dalam akuarium berbeda dengan kepadatan 10 ekor per akuarium. Penginfeksian A. hydrophila dilakukan dengan cara disuntik secara intra muskular sebanyak $0,1 \mathrm{~mL} /$ ekor ikan, dengan kepadatan bakteri $10^{6}, 10^{7}, 10^{8}$, dan $10^{9} \mathrm{CFU} / \mathrm{mL}$. Pengamatan mortalitas ikan uji dilakukan selama tujuh hari. Penghitungan LD50 mengunakan metode Reed \& Muench (1938). Berdasarkan hasil perhitungan diperoleh nilai LD50 sebesar $10^{7}$ $\mathrm{CFU} / \mathrm{mL}$.

\section{Penentuan aktivitas antagonistik}

Aktivitas antagonistik L. brevis diuji terhadap A. hydrophila dengan metode KirbyBauer (1966). Pengukuran zona bening dilakukan dengan menggunakan jangka sorong pada empat posisi diameter lingkaran dari setiap kertas cakram. Berdasarkan hasil perhitungan, diperoleh aktivitas antagonistik bakteri termasuk dalam kriteria sedang dengan rata-rata diameter zona hambat yang terbentuk sebesar 5,87 \pm 0,43 mm (Bucio et al., 2004).

\section{Penyiapan ikan uji}

Ikan uji yang digunakan adalah benih patin siam berukuran panjang rata-rata 9, $1 \pm 0,19$ $\mathrm{cm}$, berasal dari unit hatcheri Sekolah Tinggi Perikanan Jurusan Penyuluhan Perikanan Bogor. Ikan uji dipelihara dalam akuarium berukuran $90 \times 40 \times 40 \mathrm{~cm}^{3}$ dengan kepadatan 10 ekor per akuarium. Sebelum diberi perlakuan, ikan diadaptasikan terlebih dahulu selama 14 hari.

\section{Perlakuan probiotik, prebiotik, sinbiotik serta uji tantang}

Pakan yang digunakan dalam penelitian ini adalah pakan komersil dengan kandungan protein $28 \%$. Bakteri probiotik dengan konsentrasi $10^{7} \mathrm{CFU} / \mathrm{mL}$ sebanyak 1\% (Putra, 2010) dan prebiotik sebanyak 2\% (Mathious et al., 2006) dicampurkan pada pakan dengan menggunakan perekat putih telur sebanyak $2 \%$. Ikan uji diberi pakan secara at satiation, dengan frekuensi tiga kali per hari yaitu pada pukul 7.00, 12.00, dan 17.00. Pemberian probiotik, prebiotik, dan sinbiotik dilakukan 1 kali per hari pada saat siang hari selama 30 hari pemeliharaan. 


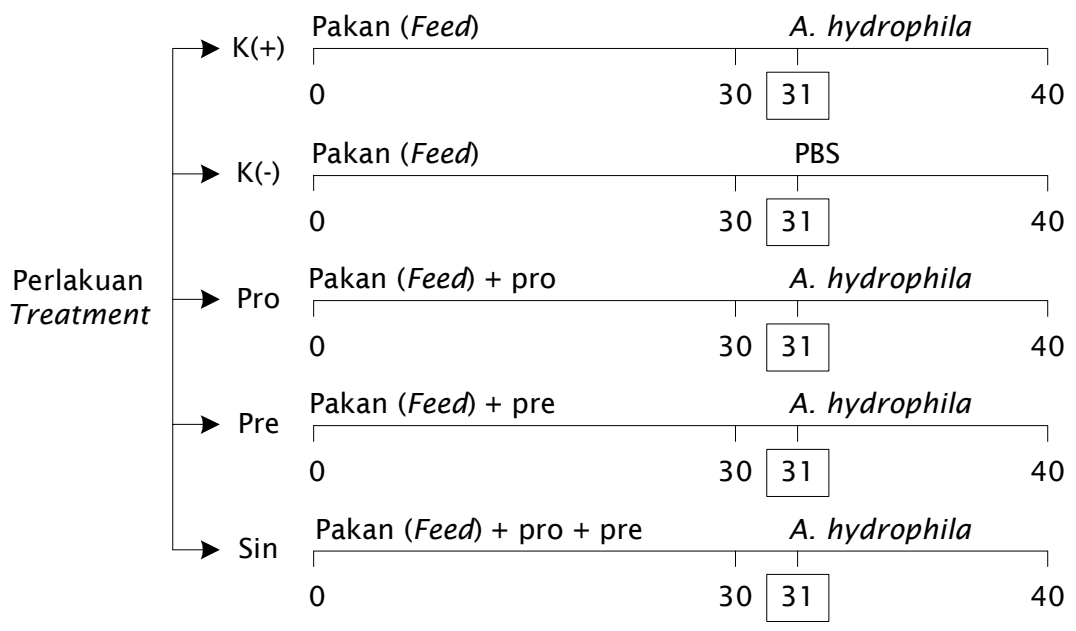

Gambar 1. Skema pelaksanaan pemeliharaan ikan dan uji tantang

Figure 1. Scheme implementation and maintenance of fish and challenge test

Penelitian terdiri atas lima perlakuan dengan masing-masing terdiri atas tiga ulangan sebagaimana ditampilkan dalam Gambar 1 .

\section{Parameter uji}

Parameter uji yang diamati selama penelitian adalah populasi Lactobacillus sp., total bakteri pada usus, total eritrosit, total leukosit, aktivitas fagositik, sintasan, pertumbuhan serta FCR benih ikan patin siam.

Pengukuran jumlah Lactobacillus sp. dan total bakteri dalam usus ikan dilakukan dengan menggunakan metode total plate count ( $\mathrm{Li}$ et al., 2009) pada hari ke-30, ke-32, serta ke-40. Usus diambil dan dihomogenkan dalam larutan $\mathrm{NaCl}(0,85 \%)$. Langkah selanjutnya adalah pengenceran berseri dengan menggunakan larutan $\mathrm{NaCl}$ 0,85\%. Perhitungan bakteri menggunakan media MRS agar (Man Rogosa Sharpe Agar) serta TSA (Trypticase soy agar).

Pengukuran gambaran darah dilakukan pada saat awal, hari ke-30, hari ke-31, hari ke34, hari ke-36 dan hari ke-38. Gambaran darah yang diamati adalah eritrosit dan total leukosit menggunakan metoda menurut Blaxhall \& Daisley (1973), serta aktivitas fagositik menggunakan metoda Anderson \& Siwicki (1993).
Pengukuran sintasan dilakukan sebelum uji tantang (hari ke-30) dan setelah uji tantang (hari ke-40). Perhitungan yang digunakan mengacu pada Effendie (1979). Pengukuran tingkat pertumbuhan dilakukan setiap empat belas hari. Perhitungan yang digunakan berdasarkan Huismann (1987). Pengukuran FCR dilakukan setelah selesai pemberian pakan perlakuan pada hari ke-30. Perhitungan yang digunakan berdasarkan NRC (1993).

\section{Analisa data}

Penelitian menggunakan Rancangan Acak Lengkap (RAL) dengan satu faktor. Data dianalisis dengan analisis ragam (ANOVA) pada selang kepercayaan 95\%. Apabila terdapat perbedaan antar perlakuan maka analisis data dilanjutkan dengan uji Duncan menggunakan program Xl-stat.

\section{HASIL DAN BAHASAN}

\section{Jumlah Lactobacillus sp. dan total bakteri di usus}

Hasil perhitungan jumlah Lactobacillus sp. serta total bakteri di usus ditampilkan pada Gambar 2. Populasi Lactobacillus sp. terdeteksi pada perlakuan probiotik dan sinbiotik, dan diduga dari jenis L. brevis, karena kedua 

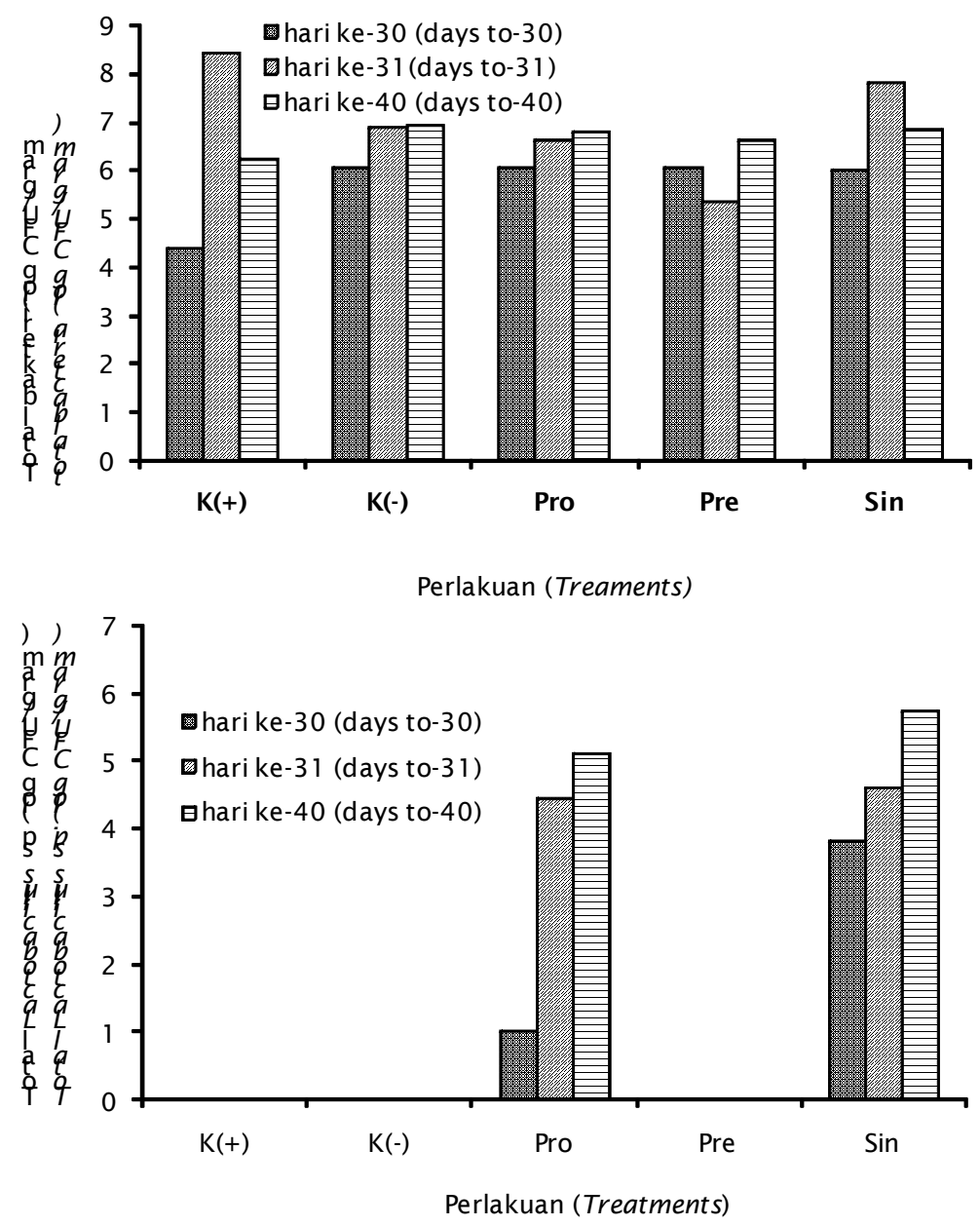

Gambar 2. Jumlah Lactobacillus sp. dan total bakteri di usus

Figure 2. Total of Lactobacillus sp. and total bacteria in the intestine

perlakuan ini diberikan asupan L. brevis. Sedangkan pada perlakuan lainnya diduga jumlah Lactobacillus sp. kurang dari $10^{2}$ (CFU/ gram) yang merupakan batas pengamatan pada penelitian ini. Bucio et al. (2004) menyatakan bahwa $L$. brevis strain $18 \mathrm{f}$ ditemukan pada usus bagian atas.

Total bakteri di usus diperoleh dengan jumlah yang hampir sama di semua perlakuan. Hal ini menunjukkan bahwa walaupun tanpa pemberian probiotik, terdapat indigenous bakteri dalam usus ikan uji.
Prebiotik dimetabolisma oleh probiotik dan menghasilkan asam lemak rantai pendek (SCFA), selanjutnya probiotik menempel dalam sel epitel usus untuk bekerja membantu kerja usus. Pemanfaatan berbagai jenis prebiotik oleh probiotik bersifat spesifik, tergantung dari kemampuan probiotik menghasilkan enzim yang dapat memetabolisma prebiotik (Manning et al., 2004). GOS dapat difermentasi oleh probiotik yang memiliki enzim â-galaktosidase (seperti Lactobacillus sp.), sedangkan FOS dapat difermentasi oleh probiotik yang memiliki enzim â-fruktosidase. 


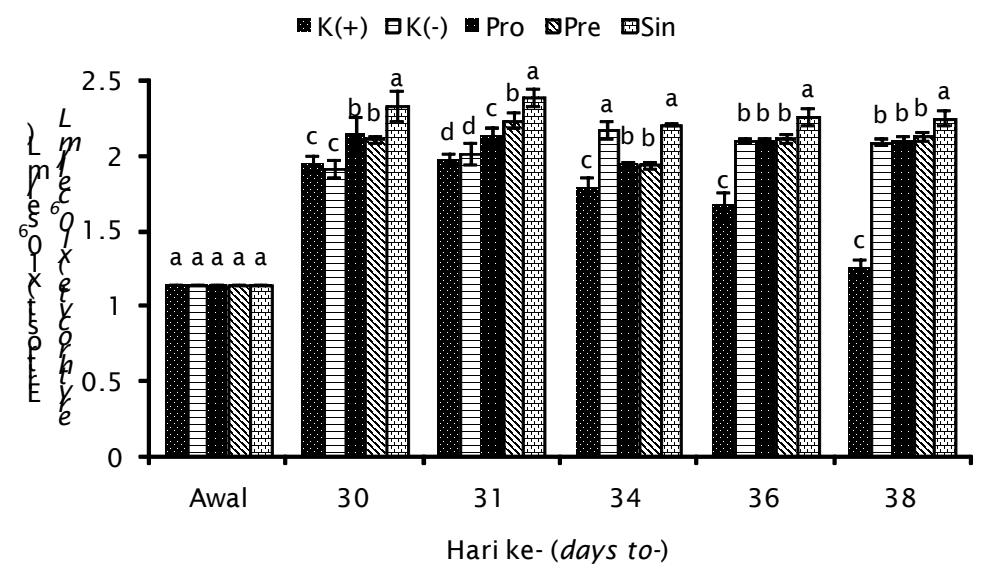

Gambar 3. Total eritrosit ikan uji pada berbagai perlakuan

Figure 3. Total fish erythrocyte tested on various treatments

\section{Gambaran darah}

Eritrosit, leukosit serta aktivitas fagositik merupakan gambaran darah yang diamati dalam penelitian ini dan hasil pengukurannya menunjukkan nilai yang bervariasi.

Hasil pengukuran eritrosit selama penelitian ditampilkan pada Gambar 3.

Berdasarkan Gambar 3 di atas, terlihat bahwa pada minggu pertama jumlah eritrosit ikan sama pada setiap perlakuan, kemudian terjadi peningkatan yang paling tinggi pada hari ke-31. Nilai eritrosit tertinggi pada hari ke-31 diperoleh pada perlakuan sinbiotik yaitu sebesar 2,39 $\pm 0,06\left(\times 10^{6} \mathrm{sel} / \mathrm{mL}\right)$, sedangkan terendah perlakuan $\mathrm{K}(+)$ yaitu sebesar $1,98 \pm 0,04\left(\times 10^{6} \mathrm{sel} / \mathrm{mL}\right)$. Berdasarkan uji lanjut Duncan, perlakuan sinbiotik berbeda nyata dengan perlakuan lainnya $(P<0,05)$.

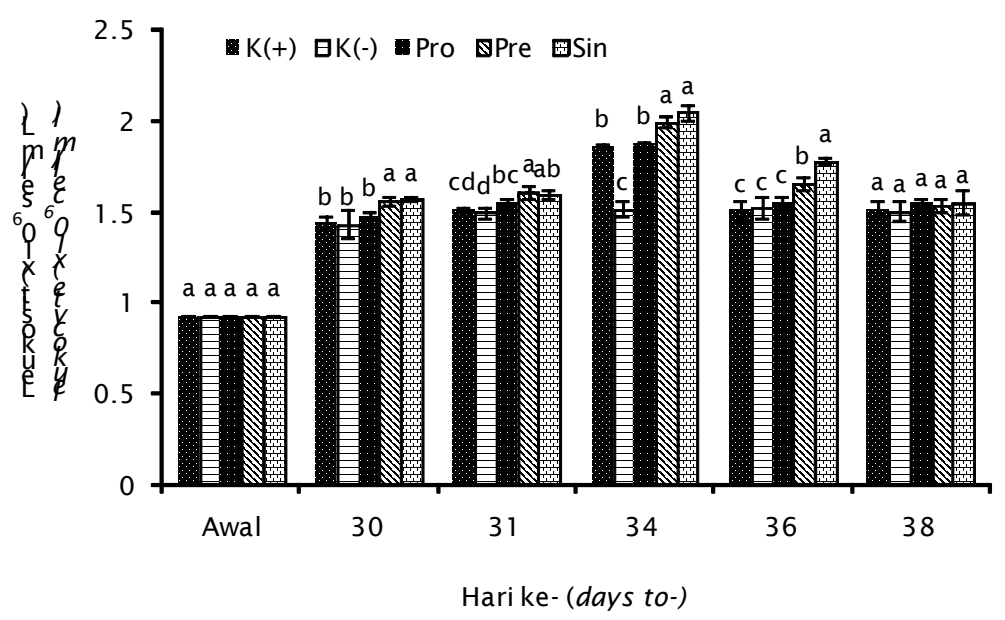

Gambar 4. Total leukosit ikan uji pada berbagai perlakuan

Figure 4. Test fish leukocyte levels in various treatments 
Menurut Kumar et al. (2013), eritrosit sebagai bagian terbesar dari sel darah memiliki jumlah bervariasi namun biasanya jumlah tersebut berkisar antara $(1,05-3,0) \times 10^{6} \mathrm{sel} /$ $\mathrm{mL}$. Rata-rata eritrosit pada berbagai perlakuan bervariasi namun masih berada pada kisaran jumlah normal untuk ikan. Tingginya nilai eritrosit pada perlakuan Sin diduga disebabkan oleh adanya asupan oligosakarida (FOS dan GOS) yang dirombak oleh probiotik menjadi asam lemak rantai pendek sebagai tambahan nutrisi bagi ikan. Hal ini menyebabkan kualitas nutrisi pada perlakuan tersebut relatif lebih baik dibanding perlakuan yang lain. Dellman \& Brown (1989) menyatakan bahwa faktor yang mempengaruhi jumlah eritrosit adalah kondisi nutrisi, jenis hewan, perbedaan induk (genetik), aktivitas fisik, dan umur.

Leukosit total darah ikan uji pada berbagai perlakuan ditampilkan pada Gambar 4. Total leukosit mengalami kenaikan tertinggi pada hari ke-34 atau tiga hari setelah uji tantang. Pada hari ke-34 ini perlakuan sinbiotik, prebiotik, probiotik serta $\mathrm{K}(+)$ memberikan nilai masing-masing sebesar $2,05 \pm 0,04\left(\times 10^{6} \mathrm{sel} /\right.$ $\mathrm{mL}) ; 2,00 \pm 0,03\left(\times 10^{6} \mathrm{sel} / \mathrm{mL}\right) ; 1,87 \pm 0,01\left(\times 10^{6}\right.$ $\mathrm{sel} / \mathrm{mL})$; serta $1,86 \pm 0,02\left(\times 10^{6} \mathrm{sel} / \mathrm{mL}\right)$. Sedangkan nilai leukosit terendah pada hari ke-34 terjadi pada perlakuan K(-) sebesar $1,51 \pm 0,04\left(\times 10^{6} \mathrm{sel} / \mathrm{mL}\right)$ karena tidak diinfeksi dengan $A$. hydrophila. Peningkatan leukosit total ini merupakan indikator respon imun terhadap infeksi, karena leukosit memegang peranan penting dalam sistem imun ikan dan tingkat keberadaannya dapat dijadikan sebagai bio-indikator status kesehatan ikan (Rawling et al., 2012).

Proses fagositik bertanggungjawab terhadap aktivasi awal dari respon terhadap peradangan sebelum diproduksinya antibodi. Proses ini dimediasi oleh sel-sel fagositik seperti monosit, neutrofil, dan macrophage. Fagositik akan diikuti oleh tingginya molekul oksigen reaktif dari aktivitas mikroorganisme seperti superoksida anion $\left(\mathrm{O}_{2}\right)$, hidrogen peroksida $\left(\mathrm{H}_{2} \mathrm{O}_{2}\right)$, dan hidroksil radikal $(\mathrm{OH})(\mathrm{Giri}$ et al., 2012). Data aktivitas fagositik selama penelitian ditampilkan dalam Gambar 5 .

Nilai aktivitas fagositik mulai mengalami peningkatan pada hari ke-30 yaitu hari terakhir pemberian perlakuan. Uji lanjut Duncan menunjukkan bahwa pada hari ke-30 dan ke31 , terdapat perbedaan yang nyata antara perlakuan sinbiotik dan prebiotik dengan $\mathrm{K}(+)$ serta K(-). Nilai aktivitas fagositik perlakuan Sin pada hari ke-30 dan ke-31 sebesar $83,33 \pm 2,31$ dan $83,00 \pm 6,08$; sedangkan perlakuan pre memiliki nilai $82,00 \pm 6,93$ serta $81,67 \pm 1,53$. Nilai $\mathrm{K}(+)$ pada hari ke-30 dan ke-31 sebesar $72,33 \pm 3,79$ dan $70,67 \pm 3,06$; adapun $\mathrm{K}(-)$ sebesar $72,67 \pm 2,31$ dan $71,33 \pm 2,52$. Penurunan nilai aktivitas fagositik terjadi mulai hari ke-36 sampai dengan hari ke-38, diduga sudah terjadi proses penghancuran bakteri patogen oleh sel fagosit.

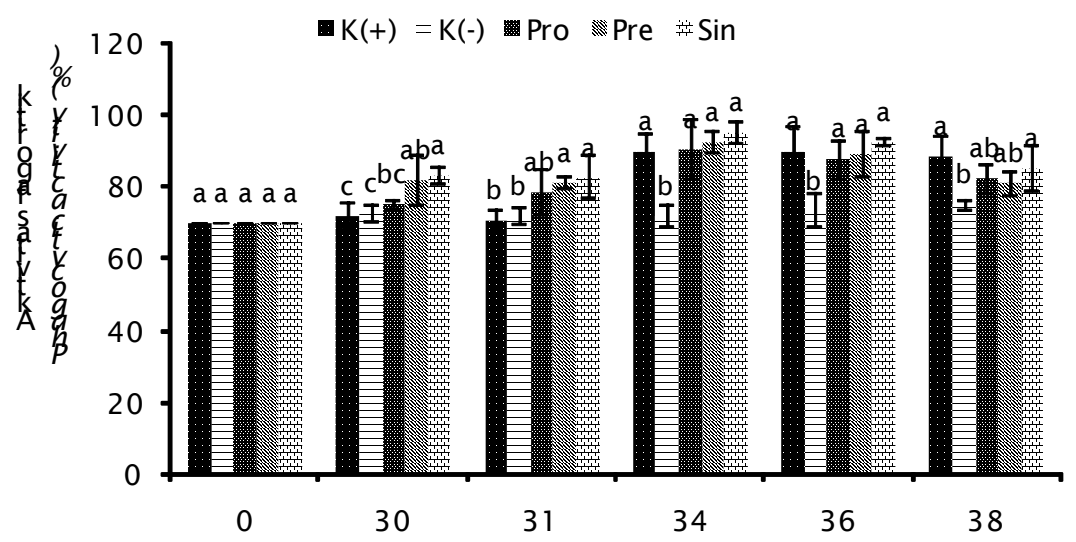

Hari ke- (days to-)

Gambar 5. Aktivitas fagositik ikan uji pada berbagai perlakuan Figure 5. Phagocytic activity of test fish at various treatments 


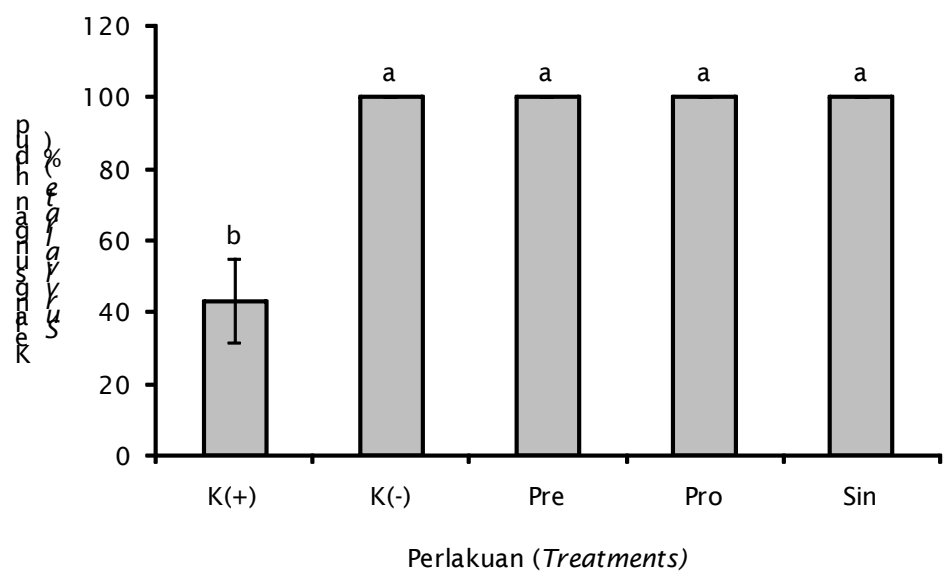

Gambar 6. Sintasan ikan uji pada berbagai perlakuan

Figure 6. Survival rate of test fish on various treatments

\section{Sintasan}

Hasil analisis keragaman $(P<0,05)$ terhadap kelangsungan hidup menunjukkan bahwa terdapat perbedaan nyata antar perlakuan $\mathrm{K}(+)$ sebesar 43,33 $\pm 11,55 \%$ dengan seluruh perlakuan yang lain (K(-), Pro, Pre, dan Sin) yaitu masing-masing sebesar $100 \pm 0,00 \%$. Grafik sintasan ditampilkan pada Gambar 6 .

Berdasarkan hasil yang diperoleh terlihat bahwa probiotik mampu menghambat pertumbuhan dari $A$. hydrophila dengan cara menghasilkan $\mathrm{H}_{2} \mathrm{O}_{2}$ Selain itu, diduga probiotik berkompetisi nutrisi dengan bakteri patogen yang ada pada usus ikan sehingga pertumbuhan bakteri patogen tersebut terhambat. Hal yang sama terjadi pada perlakuan Pre, diperkirakan tertekannya pertumbuhan patogen pada perlakuan ini adalah akibat adanya bakteri yang bersifat probiotik alami yang mampu memanfaatkan prebiotik yang diberikan. Narges et al. (2012) menyatakan bahwa penambahan FOS sebanyak 2-3\% pada pakan Caspian roach

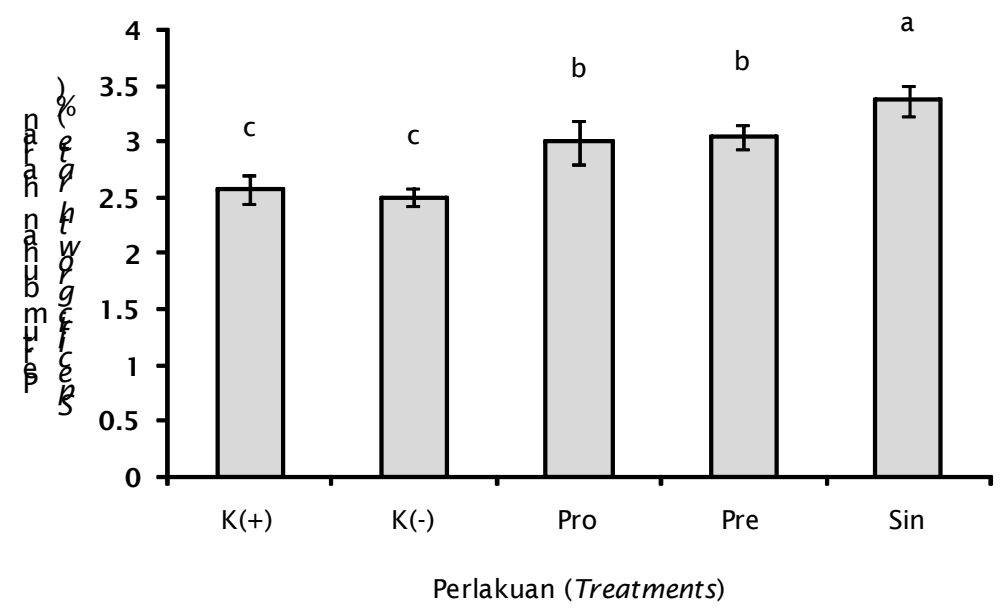

Gambar 7. Pertumbuhan harian ikan uji pada berbagai perlakuan

Figure 7. Spesific growth rate of test fish at various treatments 


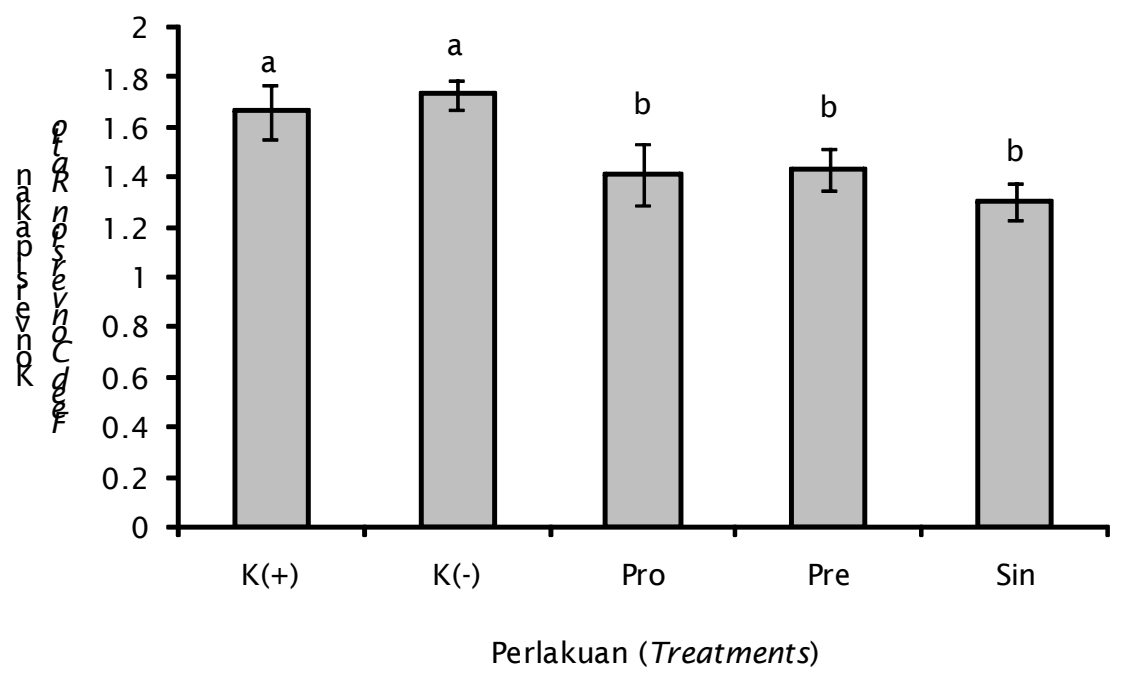

Gambar 8. Nilai FCR ikan uji pada berbagai perlakuan

Figure 8. Feed Conversion Ratio (FCR) of test fish at various treatments

(Rutilus rutilus) meningkatkan sintasan ikan uji. Barbara et al. (2008) mengemukakan pada penambahan mannanoligosaccharide (MOS), fructooligosaccharide (FOS), dan galactooligosaccharide (GOS) masing-masing dengan dosis $1 \%$ pada pakan Atlantic salmon (Salmo salar) memberikan tingkat sintasan sebesar $100 \%$.

\section{Tingkat Pertumbuhan}

Hasil pengamatan pertumbuhan menunjukkan bahwa terdapat perbedaan antar perlakuan Sin sebesar $3,370 \pm 0,14$ dengan perlakuan lain. Perlakuan Pre $(3,047 \pm 0,10)$ dan Pro $(3,001 \pm 0,20)$ tidak berbeda nyata dan antara perlakuan $\mathrm{K}(+)$ sebesar $2,578 \pm 0,13$ dan $\mathrm{K}(-)$ dengan nilai $2,505 \pm 0,07$ tidak berbeda nyata. Grafik pertumbuhan ditampilkan pada Gambar 7.

Keberadaan bakteri probiotik dalam saluran pencernaan sangat menguntungkan bagi ikan karena bakteri tersebut akan menyumbangkan exogenous enzim seperti amilase, lipase dan protease pada sistem pencernaan ikan (Narges et al., 2012). Keuntungan pertama yang terjadi dengan adanya sumbangan enzim ini adalah sistem pencernaan ikan menjadi lebih efektif sehingga pembelanjaan energi (expenditure energy) untuk proses pencernaan menjadi lebih sedikit sehingga selisih energi yang seharusnya dikeluarkan untuk pembelanjaan tersebut dapat digunakan untuk pertumbuhan. Hal kedua adalah tubuh ikan akan lebih sedikit menghabiskan energi untuk proses sintesis enzim sehingga energi tersebut dapat lebih dimanfaatkan untuk proses pertumbuhan. Narges et al. (2012) menyatakan bahwa penambahan FOS sebanyak $2-3 \%$ pada pakan larva Caspian roach memberikan tingkat pertumbuhan yang tinggi, serta berbeda nyata dengan kontrol.

\section{Feed Conversion Ratio (FCR)}

Hasil pengamatan nilai FCR menunjukkan perbedaan nyata antar perlakuan $(P<0,05)$. Berdasarkan uji lanjut, perbedaan terjadi pada perlakuan $\mathrm{K}(+)$ dan $\mathrm{K}(-)$ dengan perlakuan Pro, Pre, dan Sin. Perlakuan K(+) tidak berbeda nyata dengan $\mathrm{K}(-)$, namun berbeda nyata dengan perlakuan Pro, Pre, dan Sin.

FCR ikan uji berkorelasi positif dengan tingkat pertumbuhan, dengan nilai perlakuan sin, pre, dan pro masing-masing sebesar $1,305 \pm 0,08 ; 1,414 \pm 0,13 ; 1,431 \pm 0,08$. Begitu pula pada tingkat pertumbuhan yang menunjukkan bahwa besaran nilai yang diperoleh secara berurutan adalah sin, pre, dan pro. Hal ini terjadi karena diduga pada perlakuan sin, pre, dan pro jumlah populasi bakteri yang menguntungkan di dalam usus 
ikan uji mengalami peningkatan dibandingkan kontrol, sehingga enzim yang mendukung sistem pencernaan (protease, amilase, lipase) akan meningkat (Narges et al., 2012).

\section{KESIMPULAN}

Populasi Lactobacillus sp. di usus pada perlakuan probiotik dan sinbiotik berkisar antara $10^{1}$ sampai $10^{6}$ (CFU/gram). Total eritrosit, total leukosit, indeks fagositik pada perlakuan prebiotik, probiotik, dan sinbiotik menunjukkan hasil yang lebih baik dari kontrol pada beberapa waktu pengamatan. Tingkat sintasan terendah diperoleh pada perlakuan $\mathrm{K}(+)$, sedangkan empat perlakuan lainnya memperoleh nilai $100 \%$. Tingkat pertumbuhan harian serta FCR berbeda nyata antar perlakuan sinbiotik, prebiotik, probiotik dengan kontrol (+) dan (-). Nilai pertumbuhan harian terbaik dicapai pada perlakuan sinbiotik sebesar $3,37 \pm 0,14$. Perlakuan sin, pre, pro memberikan nilai yang lebih baik pada total eritrosit, total leukosit, aktivitas fagositik, sintasan, pertumbuhan, dan FCR dibandingkan kontrol.

\section{DAFTAR ACUAN}

Anderson, D.P. \& Siwicki, A.K. 1993. Basic hematology and serology for fish health programs. Paper presented in second symposium on diseases in Asean Aquaculture "Aquatic Animal Health and The Environment". Phuket, Thailand. 25-29 $9^{\text {th }}$ October 1993, p. 185-202.

Angelis, M.D. \& Gobbetti, M. 2011 . Lactic Acid Bacteria Lactobacillus spp.: General Characteristics. Encyclopedia of Dairy Sciences (Second Edition), p. 78-90

AOAC (Assosiation of Official Agricultural Chemist). 1999. Official Methods of Analysis. $16^{\text {th }}$ ed Volume II. Maryland. USA, p. 151-160.

Barbara Grisdale, Helland, H.J., Ståle, J., Gatlin, D.M. 2008. The effects of dietary supplementation with mannanoligosaccharide, fructooligosaccharide or galactooligosaccharide on the growth and feed utilization of Atlantic salmon (Salmo salar). Aquaculture, 283: 163-167.

Bauer, A.W., Kirby, W.M.M., Sherris, J.C., \& Turck, M. 1966. Antibiotic susceptibility testing by a standardized single disk method. Am. J. Clin. Pathol., 36: 493-496.

Blaxhall, P.C. \& Daisley, K.W. 1973. Routine haematologycal methods for use with fish blood. J. Fish Biology, 5: 577-581.

Bucio, A., Hartemink, R., Shciama, J.W., \&
Rombuts ,F.M. 2004. Screening of Lactobacilli from fish intestines to select a probiotic for warm freshwater fish. Bioscience microflora, 23: 21-30.

Davis, L.M., Martinez, L., Walter, J., \& Hutkins, R. 2010. A close dependent impact of prebiotic galactooligosaccharides on the intestinal microbiota of healty adults. International Journal of Food Microbiology, 144: 85-292.

Dellman, H.D. \& Brown, E.M. 1989. Buku Teks Histologi Veteriner. Hartono (Penerjemah). UI Press. Jakarta, 108-143 hlm.

Douglas, L.C. \& Sanders, M.E. 2008. Perspectives in practice probiotics and prebiotics in dietetics practice. Am Siet Assoc, 108: 510-521.

Effendie, M.I. 1979. Metode biologi perikanan. Yayasan Dewi Sri, Bogor, $111 \mathrm{hlm}$.

Giri, S.S., Sen, S.S., \& Sukumaran, V. 2012 . Effects of dietary supplementation of potential probiotic Pseudomonas aeruginosa VSG- 2 on the innate immunity and disease resistance of tropical freshwater fish, Labeo rohita. Fish \& Shellfish Immunology, 32: 1,135-1,140.

Huisman,E.A. 1987. Principles of fish production. Departemen of fish culture and fisheries Wageningen Agricultural University. Wageningen/Netherland, $122 \mathrm{pp}$.

Kumar, S., Raman, R.P., Pandey, P.K., Mohanty, S., Kumar, A., \& Kumar, K. 2013. Effect of orally administered Azadirachtin on nonspecific immune parameters of goldfish Carassius auratus (Linn., 1758) and resistance against Aeromonas hydrophila. Fish and Shellfish Immunology. doi: 10.1016/ j.fsi.2012.11.038.

Li, J., Beiping, T., \& Kangsen, M. 2009. Dietary probiotic Bacillus OJ and isomaltooligosaccharides influence the intestine microbial populations, immune responses and resistance to white spot syndrome virus in shrimp (Litopenaeus vannamei). Aquaculture, 291: 35-40.

Manning, T.S., Rastall, F., \& Gibson G. 2004. Prebiotics and lactic acid bacteria. Microbiology and functional aspects $3^{\text {th }}$ edition. Revised and Expanded. Marcel dekker Inc. New york, p. 419-430.

Mathious, A.S., Gatesoupe, F.J., Hervi, M., Metailler, R., \& Ollevier, F. 2006. Effect of dietary inulin and oligosaccharides as prebiotics for weaning turbot, Psetta maxima. Aquaculture International, 14: 219-229. 
Merrifield, D.L., Dimitroglou, A., Foey, A., Davies, S.J., Baker, R.T.M., Bøgwald, J., Castex, M., \& Ringø, E. 2010. Review: The Current status and future focus of probiotic and prebiotik applications for salmonids, Aquaculture, 302: 1-18.

Narges, S., Hoseinifar, S.H., Merrifield, D.L., \& Barati, M. 2012. Dietary supplementation of fructooligosaccharide (FOS) improves the innate immune response, stess resistence, digestive enzyme activitis and growth performance of Caspian roach (Rutilus rutilus) fry. Fish and Shellfish Immunology, 32: 316-321.

Nayak, S.K. 2010 . Probiotics and immunity: a fish perspective. Fish and shellfish immunology, 29: 2-14.

National Research Council (NRC). 1993. Nutrient requirements of fish. Sub committee on fish nutrition, National Research Council. National Academic Press (USA), 114 pp.

Park, C.W., Youn, M., Jung, Y.M., Kim, H., Jeong, Y., Lee, H.K., Kim, H.O., Lee, I., Lee, S.W., Kang, K.H., \& Park, Y.H. 2008. New functional probiotic Lactobacillus sakei probio 65 allviats atropic symptoms in the mouse. J. of Medicinal food, 11: 405-412.

Putra, A.N. 2010 . Aplikasi probiotik, prebiotik, dan sinbiotik untuk meningkatkan kinerja pertumbuhan ikan nila (Oreochromis niloticus). Tesis. Bogor. Sekolah Pascasarjana, Institut Pertanian Bogor, 29 hlm.

Rawling, M.D., Merrifield, D.L., Snellgrove, D.L., Kühlwein, H., Adams, A., \& Davies, S.J. 2012. Haemato-immunological and growth response of mirror carp (Cyprinus carpio) fed a tropical earthworm meal in experimental diets. Fish \& Shellfish Immunology, 32: 1002-1007.

Reed, L.J. \& Muench, H. 1938. A simple method of estimating fifty percent endpotants. The American Journal of Hygiene, 27: 493-497.

Rey.,A., Verján, N., Ferguson, H.W., \& Iregui, C. 2009. Pathogenesis of Aeromonas hydrophila strain KJ99 infection and its extracellular products in two species of fish. Veterinary Record, 164: 493-499.

Verschuere, L., Rombaut, L., Sorgeloos, P., \& Verstraete, W. 2000. Probiotic bacteria as biological control agents in aquaculture. J. Microbiology and Molecular Biology Reviews, 64: 655-671. 